\title{
Scenarios for the Hanford Immobilized Low-Activity Waste (ILAW) Performance Assessment
}

Prepared for the U.S. Department of Energy

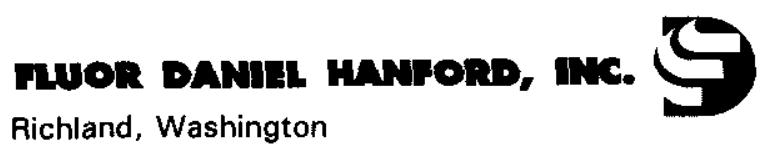

Hanford Management and Integration Contractor for the

U.S. Department of Energy under Contract DE-AC06-96RL13200

Approved for Public Release; Further Dissemination Unlimited 


\section{INFORMATION CLEARANCE FORM}

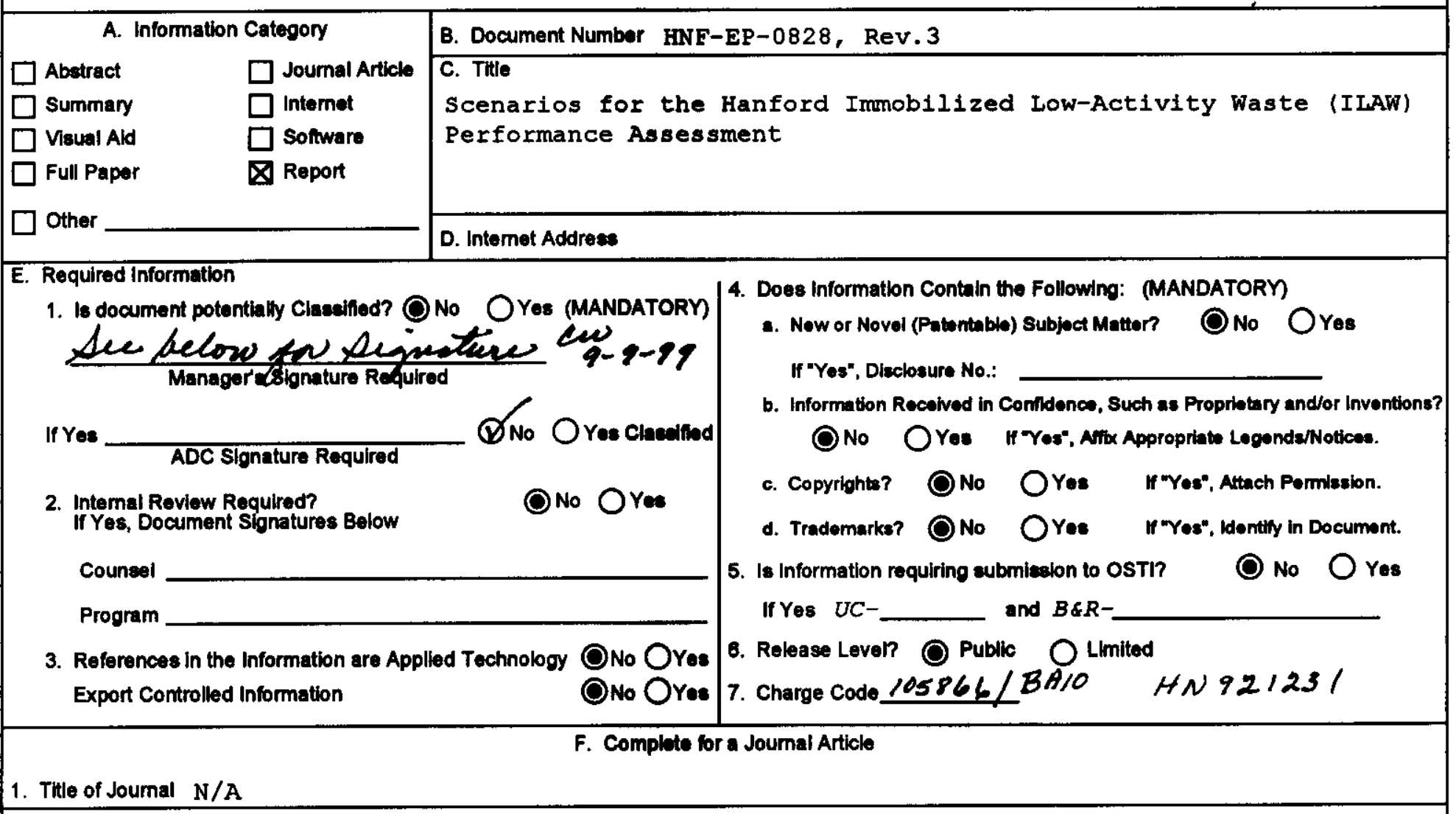

1. Title of Journal $\mathrm{N} / \mathrm{A}$

G. Complete for a Presentation

1. Title for Conference or Meeting

2. Group Sponsoring

3. Date of Conference

5. Will Information be Published in Proceedings? ONo OYes

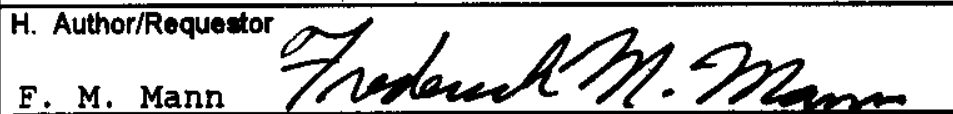

(Print and Sign)

I. Reviewers

Yes Print

General Counsel

Office of External Affairs

DOE-RL

Other

Other $\square$ $\square$

$\nabla \quad$ R. W. Root
4. City/State

6. Will Material be Handed Out? $\bigcirc$ No $\bigcirc$ Yes Responsible Manager R. J. Puigh Signature Public $\mathrm{Y} / \mathrm{N}$ (If $\mathrm{N}$, complete J)

$\mathrm{Y} / \mathrm{N}$

$\mathrm{Y} / \mathrm{N}$

$\mathrm{Y} / \mathrm{N}$

- $\mathrm{Y} / \mathrm{N}$

$\mathrm{Y} / \mathrm{N}$

J. If Information Includes Sensitve Information and is not to be released to the Public indicate category folow.
$\square$ Applied Technology
$\square$ Protected CRADA
$\square$ PersonalPrivate
$\square$ Export Controlled
$\square$ Proprietary
$\square$ Procurement-Sensitive
$\square$ Business-Sensitive
$\square$ Patentable
$\square$ Predecisional
Other (Specify)

$\square$ UCNI

K. If Additional Comments, Please Attach Separate Sheet 
HNF-EP-0828

Revision 3

UC-630

\section{Scenarios for the Hanford Immobilized Low-Activity Waste (ILAW) Performance Assessment}

Prepared by:

F. M. Mann

Fluor Daniel Northwest, Inc.

Date Published

August 1999

Prepared for the U.S. Department of Energy

FUOR DANIIL HANTORP,

Richland, Washington

Hanford Management and Integration Contractor for the

U.S. Department of Energy under Contract DE-AC06-96RL13200

Approved for Public Release; Further Dissemination Unlimited 


\section{LEGAL DISCLAIMER}

This report was prepared as an account of work sponsored by an agency of the United States Government. Neither the United States Government nor any agency thereof, nor any of their employees, nor any of their contractors, subcontractors or their employees, makes any warranty, express or implied, or assumes any legal liability or responsibility for the accuracy, completeness, or any third party's use or the results of such use of any information, apparatus, product, or process disclosed, or represents that its use would not infringe privately owned rights. Reference herein to any specific commercial product, process, or service by trade name, trademark, manufacturer, or otherwise, does not necessarily constitute or imply its endorsement, recommendation, or favoring by the United States Government or any agency thereof or its contractors or subcontractors. The views and opinions of authors expressed herein do not necessarily state or reflect those of the United States Government or any agency thereof.

This report has been reproduced from the best available copy.

Available in paper copy and microfiche.

Available to the U.S. Department of Energy and its contractors from

U.S. Department of Energy

Office of Scientific and Technical Information (OSTI)

P.O. Box 62

Oak Ridge, TN 37831

(615) $576-8401$

Available to the public from the U.S. Department of Commerce

National Technical Information Service (NTIS)

5285 Port Royal Road

Springfield, VA 22161

(703) $487-4650$

Printed in the United States of America

DISCLM-1.CHP (8-95) 


\section{RELEASE AUTHORIZATION}

Document

Number:
HNF-EP-0826, Rev. 3
Document

Title:
Performance Objectives for the Hanford Immobilized

Low-Activity Waste (ILAW) Performance Assessment

\section{This document, reviewed in accordance with DOE Order 241.1, "Scientific and Technical Information Management," and DOE G 241.1-1, "Guide to the Management of Scientific and Technical Information," does not contain classified or sensitive unclassified information and is:}

\section{APPROVED FOR PUBLIC RELEASE}

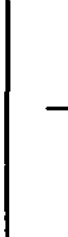

\section{Thestex}

C. Witingarm

Document Control/Information Clearance

Reviewed for Applied Technology, Business Seneitive, Classified, Copyrighted, Export Controlled, Patent, Personal/Private, Proprietary, Protected CRADA, Trademark, Unclassified Controlled Nuclear Information.

LEGAL DISCLAIMER. This report was prepared as an account of work sponsored by an agency of the United States Government. Neither the United States Government nor any agency thereof, not any of their employees, nor any of their contractors, subcontractors or their employees, makes any warranty, express or implied, or assumes any legal liability or responsibility for the accuracy, completeness, or any third party's use or the results of such use of any information, apparatus, product, or process disclosed, or represents that its use would not infringe privately owned rights. Reference herein to any specific conmercial product, process, or service by trade name, trademark, manufacturer, or otherwise, does not necessarily constitute or imply its endorsement, recomendation, or favoring by the Uni ted States Government or any agency thereof or its contractors or subcontractors. The views and opinions of authors expressed herein do not necessarily state or reflect those of the United States Government or any agency thereof. This report has been reproduced from the best available copy. Printed in the United States of America. 


\section{Table of Contents}

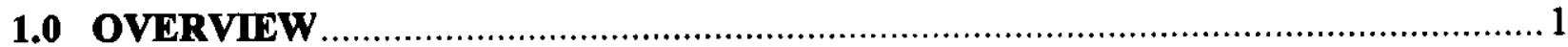

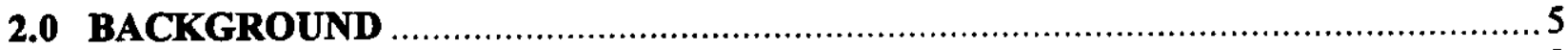

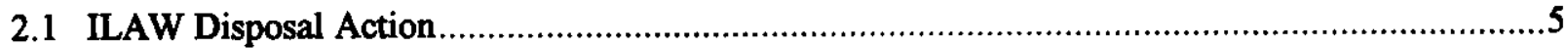

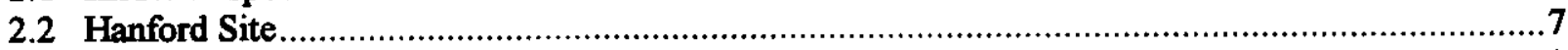

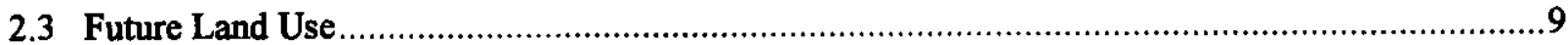

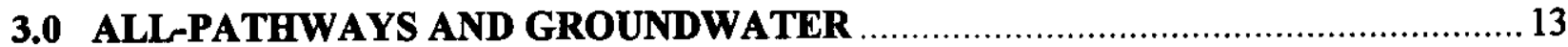

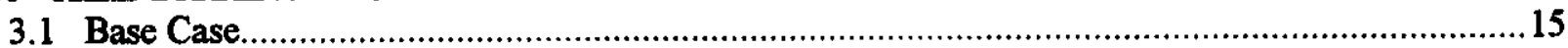

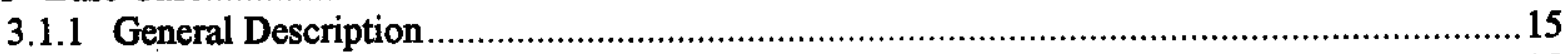

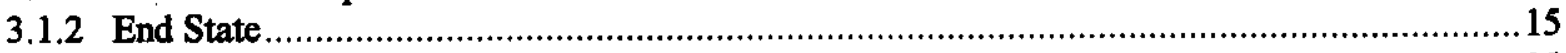

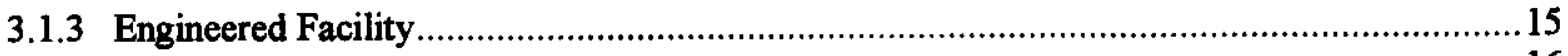

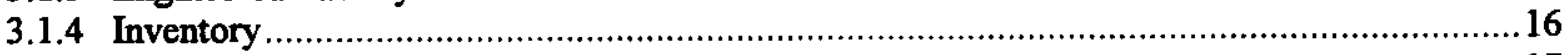

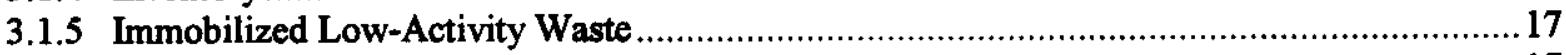

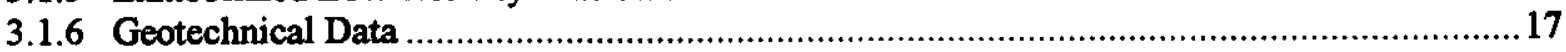

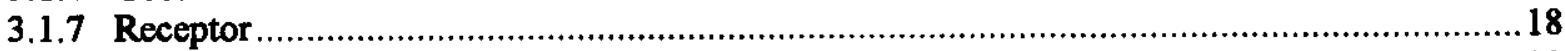

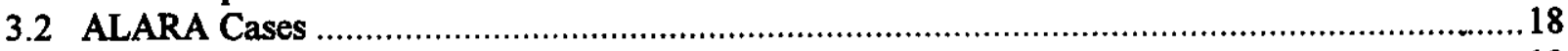

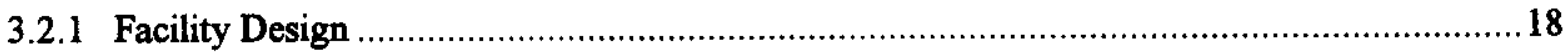

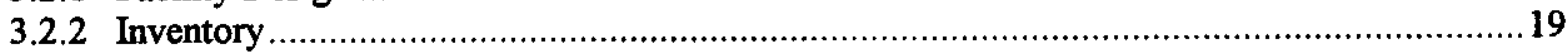

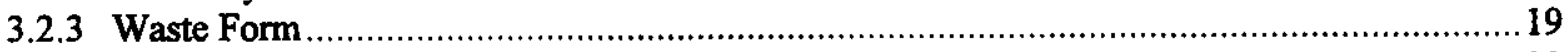

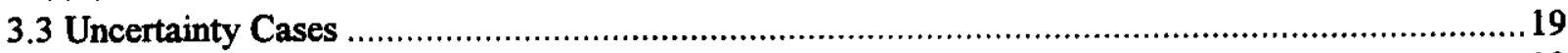

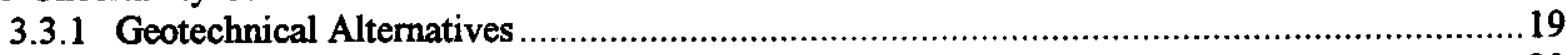

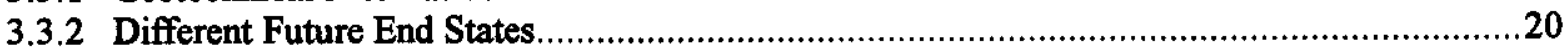

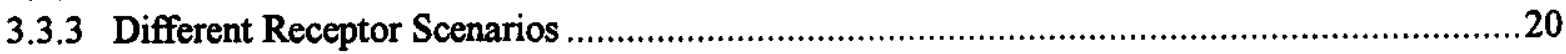

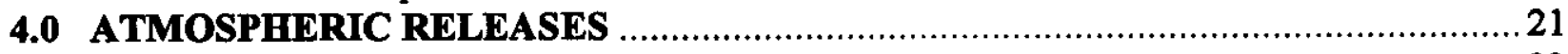

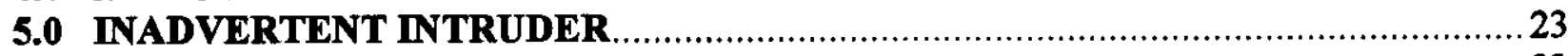

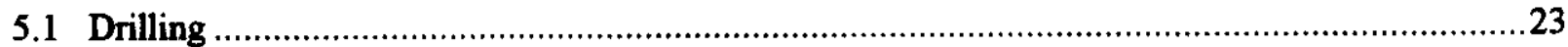

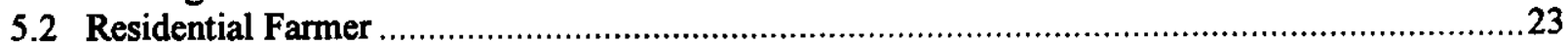

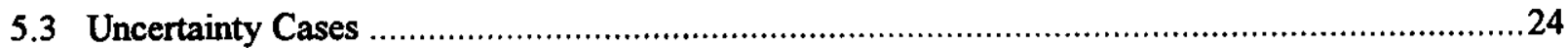

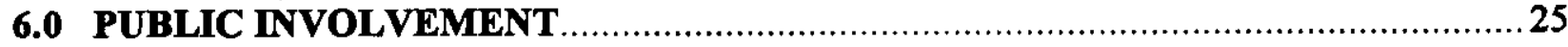

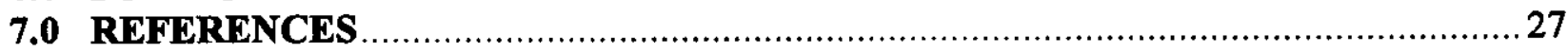

\section{List of Tables}

1.1 Radiological Performance Objectives ......................................................

1.2 Performance Goals for Inorganic Materials ................................................ 3

1.3 Performance Goals for Organic Materials ................................................... 3

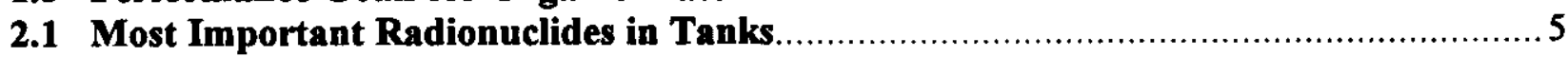

\section{List of Figures}

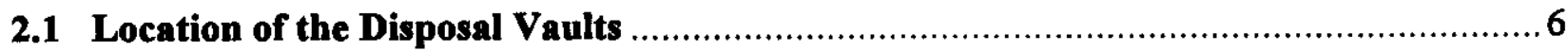

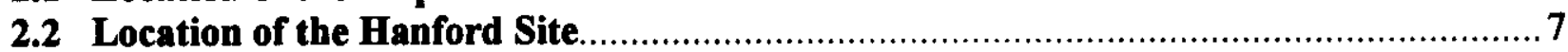

2.3 Location of the Future Site Boundary ......................................................... 11

3.1 Sequential Steps for Groundwater Pathway ............................................. 14 
HNF-EP-0828, Rev.3

\section{Acronyms}

$\begin{array}{ll}\text { ALARA } & \text { as low as reasonable achievable } \\ \text { CFR } & \text { Code of Federal Register } \\ \text { DOE } & \text { Department of Energy } \\ \text { HFSUWG } & \text { Hanford Future Site Uses Working Group } \\ \text { ILAW } & \text { immobilized low-activity waste } \\ \text { NRC } & \text { Nuclear Regulatory Commission } \\ \text { PA } & \text { performance assessment } \\ \text { WAC } & \text { Washington Administrative Code }\end{array}$




\subsection{OVERVIEW}

The purpose of the next version of the Hanford Immobilized Low-Activity Tank Waste (ILAW) Performance Assessment (ILAW PA) is to provide an updated estimate of the long-term human health and environmental impact of the disposal of ILAW and to compare these estimates against performance objectives displayed in Tables 1, 2, and 3 (Mann 1999a). Such a radiological performance assessment is required by U.S. Department of Energy (DOE) Orders on radioactive waste management (DOE 1988a and DOE 1999a). This document defines the scenarios that will be used for the next update of the PA that is scheduled to be issued in 2001. Since the previous performance assessment (Mann 1998) was issued, considerable additional data on waste form behavior and site-specific soil geotechnical properties have been collected. In addition, the 2001 ILAW PA will benefit from improved computer models and the experience gained from the previous performance assessment. However, the scenarios (that is, the features, events, and processes analyzed in the performance assessment) for the next PA are very similar to the ones in the $1998 \mathrm{PA}$.

The scenarios analyzed as part of the base case studies are chosen to represent likely situations to demonstrate compliance with the performance objectives. Other scenarios are chosen to represent situations that demonstrate the uncertainties or sensitivities of key parameters surrounding the best case. Finally, reasonably bounding scenarios are chosen to provide an understanding of the limits of performance.

The scenarios are based on guidance from the Department of Energy (1999a, 1999b, 1999c, 1999d, and 1999e) and from the U.S. Nuclear Regulatory Commission (NRC 1988 and NRC 1997). The scenarios are also based on those used in the 1998 ILAW PA (Mann 1998) and other Hanford Site performance assessments (Kincaid 1995, Wood 1995, and Wood 1996). This document updates the document (Mann 1994) which defined the scenarios used in the 1998 ILAW PA.

This document provides a general description of the scenarios that will be analyzed. A series of documents (data packages) [Fayer 1999, Kaplan 1999, Khaleel 1999, Meyer 1999, McGrail 1999, Prosser 1999, Puigh 1999, Reidel 1999, Rittmann 1999, and Wootan 1999] that cover each of the various data areas important to the performance assessment will be published later this year. These data packages will provide the values for all of the parameters used in the analyses as well as the associated uncertainty information. Each of these data packages will have a formal review plan that will include external review. chapters,

Chapter 2 provides background information about the ILAW disposal. The next three
3. All-Pathways and Groundwater
4. Releases to the Atmosphere
5. Inadvertent Intruder,

define the scenarios for each set of performance objectives. Since contamination transport to surface water (such as the Columbia River) will be through the groundwater pathway, that 
HNF-EP-0828, Rev.3

pathway is also described in Chapter 3. Chapter 6 describes the public involvement process used for this document.

\section{TABLE 1.1 RADIOLOGICAL PERFORMANCE OBJECTIVES}

\begin{tabular}{|c|c|}
\hline \multicolumn{2}{|c|}{ Protection of General Public and Workers ${ }^{a, b}$} \\
\hline $\begin{array}{l}\text { All-pathways dose from only this facility } \\
\text { All-pathways dose including other Hanford Site sources }\end{array}$ & $\begin{array}{l}25 \text { mrem in a year }^{\text {d, }}, \\
100 \text { mrem in a year }^{\circ, i}\end{array}$ \\
\hline \multicolumn{2}{|c|}{ Protection of an Inadvertent Intruder ${ }^{\mathrm{c}, \mathrm{f}}$} \\
\hline $\begin{array}{l}\text { Acute exposure } \\
\text { Continuous exposure }\end{array}$ & $\begin{array}{r}500 \text { mrem } \\
100 \text { mrem in a year }\end{array}$ \\
\hline \multicolumn{2}{|c|}{ Protection of Groundwater Resources ${ }^{b, d, j}$} \\
\hline $\begin{array}{c}\text { Alpha emitters } \\
{ }^{226}{ }_{R a}+{ }^{228} \\
R a \\
\text { All others (total) } \\
\text { Beta and photon emitters }\end{array}$ & $\begin{array}{r}5 \mathrm{pCi} / \ell \\
15 \mathrm{pCi} / \ell \\
4 \text { mrem in a year }\end{array}$ \\
\hline \multicolumn{2}{|c|}{ Protection of Surface Water Resources ${ }^{b, z}$} \\
\hline $\begin{array}{l}\text { Alpha emitters } \\
{ }^{226} \mathrm{Ra}+{ }^{228} \mathrm{Ra} \\
\text { All others (total) } \\
\text { Beta and photon emitters }\end{array}$ & $\begin{array}{r}0.3 \mathrm{pCi} / \ell^{j} \\
15 \mathrm{pCi} / \ell^{j} \\
1 \text { mrem in a year }^{k}\end{array}$ \\
\hline \multicolumn{2}{|c|}{ Protection of Air Resource ${ }^{b, \bar{r}, 1}$} \\
\hline $\begin{array}{l}\text { Radon (flux through surface) } \\
\text { All other radionuclides }\end{array}$ & $\begin{array}{l}20 \mathrm{pCi} \mathrm{m}^{-2} \mathrm{~s}^{-1} \\
10 \mathrm{mrem} \text { in a year }\end{array}$ \\
\hline
\end{tabular}

- All doses are calculated as effective dose equivalents; all concentrations are in water taken from a well. Values given are in addition to any existing amounts or background.

b Evaluated for 1,000 and 10,000 years, but calculated to the time of peak or 10,000 years, whichever is longer.

c Evaluated for 500 years, but calculated to 1,000 years.

d Evaluated at the point of maximal exposure, but no closer than 100 meters ( 328 feet) from the disposal facility.

Evaluated at the 200 East Area fence.

Evaluated at the disposal facility.

B Evaluated at the Columbia River, no mixing with the river is assumed.

h Main driver is DOE Orders on Radioactive Waste Management (DOE 1988a and DOE 1999a)

i Main driver is DOE Order 5400.5, Radiation Protection of the Public and the Environment (DOE 1993).

j Main driver is "National Primary Drinking Water Regulations (40 CFR 141).

k Main driver is "Washington State Surface Water Standards (WAC 173-201A)

${ }^{1}$ Main driver is "National Emission Standards for Hazardous Air Pollutants (40 CFR 61H and 40 CFR 61Q) 


\section{Table 1.2 Performance Goals for Inorganic Materials}

\begin{tabular}{|c|c|c|c|c|}
\hline Chemical & \multicolumn{2}{|c|}{ Groundwater } & \multicolumn{2}{|c|}{ Surface Waters } \\
\hline Ammonia & & & 4.0 & $\mathrm{mg} / \mathrm{l}$ \\
\hline Antimony & 0.006 & $\mathrm{mg} / \mathrm{l}$ & 0.006 & $\mathrm{mg} / \mathrm{l}$ \\
\hline Arsenic & 0.00005 & $\mathrm{mg} / \mathrm{l}$ & 0.05 & $\mathrm{mg} / 1$ \\
\hline Barium & 1.0 & $\mathrm{mg} / \mathrm{l}$ & 2.0 & $\mathrm{mg} / \mathrm{l}$ \\
\hline Beryllium & 0.004 & $\mathrm{mg} / \mathrm{l}$ & 0.004 & $\mathrm{mg} / \mathrm{l}$ \\
\hline Cadmium & 0.005 & $\mathrm{mg} / \mathrm{l}$ & 0.00077 & $\mathrm{mg} / \mathrm{l}$ \\
\hline Chlorine & 250. & $\mathrm{mg} / \mathrm{l}$ & 230. & $\mathrm{mg} / \mathrm{l}$ \\
\hline Chromium & 0.05 & $\mathrm{mg} / \mathrm{l}$ & 0.011 & $\mathrm{mg} / \mathrm{L}$ \\
\hline Copper & 1.0 & $\mathrm{mg} / \mathrm{l}$ & 0.0078 & $\mathrm{mg} / \mathrm{l}$ \\
\hline Cyanide & 0.2 & $\mathrm{mg} / \mathrm{l}$ & 0.0052 & $\mathrm{mg} / 1$ \\
\hline Fluoride & 4.0 & $\mathrm{mg} / \mathrm{l}$ & 4.0 & $\mathrm{mg} / \mathrm{l}$ \\
\hline Iron & 0.3 & $\mathrm{mg} / \mathrm{l}$ & & \\
\hline Lead & 0.05 & $\mathrm{mg} / \mathrm{l}$ & 0.0015 & $\mathrm{mg} / \mathrm{l}$ \\
\hline Manganese & 0.05 & $\mathrm{mg} / \mathrm{l}$ & & \\
\hline Mercury & 0.002 & $\mathrm{mg} / \mathrm{l}$ & 0.000012 & $\mathrm{mg} / \mathrm{l}$ \\
\hline Nickel & & & 0.115 & $\mathrm{mg} / 1$ \\
\hline Nitrate as $\mathbf{N}$ & 10. & $\mathrm{mg} / \mathrm{l}$ & 10. & $\mathrm{mg} / \mathrm{l}$ \\
\hline Nitrite as $\mathbf{N}$ & 1.0 & $\mathrm{mg} / \mathrm{l}$ & 1.0 & $\mathrm{mg} / \mathrm{l}$ \\
\hline Nitrite plus Nitrate & 10. & $\mathrm{mg} / \mathrm{l}$ & 10. & $\mathrm{mg} / 1$ \\
\hline Selenium & 0.01 & $\mathrm{mg} / \mathrm{l}$ & 0.005 & $\mathrm{mg} / \mathrm{l}$ \\
\hline Silver & 0.05 & $\mathrm{mg} / \mathrm{l}$ & & \\
\hline Sulfate & 250. & $\mathrm{mg} / \mathrm{l}$ & & \\
\hline Thallium & 0.002 & $\mathrm{mg} / \mathrm{l}$ & & \\
\hline Zinc & 5.0 & $\mathrm{mg} / \mathrm{l}$ & 0.072 & $\mathrm{mg} / \mathrm{l}$ \\
\hline
\end{tabular}

No entry in a cell indicates that no limit was found.

\section{Table 1.3 Performance Goals for Organic Compounds a}

\begin{tabular}{|c|c|c|c|}
\hline CAS \# & Constituent (a) & Groundwater & Surface Waters \\
\hline $56-23-5$ & Carbon tetrachloride & $0.0003 \mathrm{mg} / \mathrm{l}$ & $0.005 \mathrm{mg} / 1$ \\
\hline $67-66-3$ & Chloroform & $0.007 \mathrm{mg} / \mathrm{l}$ & \\
\hline $71-43-2$ & Benzene & $0.001 \mathrm{mg} / 1$ & $0.005 \mathrm{mg} / 1$ \\
\hline $71-55-6$ & 1,1,1-Trichloroethane & $0.003 \mathrm{mg} / \mathrm{l}$ & $0.2 \mathrm{mg} / 1$ \\
\hline $75-09-2$ & Dichloromethane (Methylene Chloride) & $0.005 \mathrm{mg} / \mathrm{l}$ & $0.005 \mathrm{mg} / 1$ \\
\hline $79-00-5$ & 1,1,2-Trichloroethane & $0.005 \mathrm{mg} / \mathrm{l}$ & $0.005 \mathrm{mg} / \mathrm{l}$ \\
\hline $79-01-6$ & 1,1,2-Trichloroethylene & $0.005 \mathrm{mg} / \mathrm{l}$ & $0.005 \mathrm{mg} / \mathrm{l}$ \\
\hline $95-47-6$ & o-Xylene & $0.7 \quad \mathrm{mg} / \mathrm{l}$ & $0.7 \mathrm{mg} / \mathrm{l}$ \\
\hline $100-41-4$ & Ethyl benzene & $\mathrm{mg} / \mathrm{l}$ & $\mathrm{mg} / \mathrm{l}$ \\
\hline $106-46-7$ & 1,4-Dichlorobenzene & $0.004 \mathrm{mg} / 1$ & $0.075 \mathrm{mg} / \mathrm{l}$ \\
\hline $108-88-3$ & Toluene & $1.0 \mathrm{mg} / \mathrm{l}$ & $1.0 \mathrm{mg} / \mathrm{l}$ \\
\hline $127-18-4$ & $1,1,2,2$-Tetrachloroethene & $0.005 \mathrm{mg} / 1$ & $0.005 \mathrm{mg} / \mathrm{l}$ \\
\hline
\end{tabular}

(a) Greater than 100 analytical detects in tank waste or greater than 20 analytical detects in TWINS

Solid/Liquid Hits. Taken from Wiemers 1998.

No entry in a cell indicates that no limit was found. 
HNF-EP-0828, Rev.3

This page intentionally left blank 


\subsection{BACKGROUND}

for

To better understand the scenarios selected, some background information is presented

- the disposal action,

- the Hanford Site,

- the expected future land use.

Only a summary is given here. More information is provided in the Hanford Immobilized LowActivity Tank Waste Performance Assessment (Mann 1998).

\subsection{ILAW Disposal Action}

In the 200 Areas of the Hanford there are presently 54 million gallons of high-level radioactive and hazardous waste stored in 177 underground tanks (See Figure 1). These wastes are the by-products of the production of special nuclear material for the U.S. defense effort. The inventory in the underground tanks (Kupfer 1998) for the radionuclides found most important in the 1998 ILAW PA is displayed in Table 2.1.

\section{Table 2.1 Most Important Radionuclides in Tanks}

\begin{tabular}{|l|r|}
\multicolumn{2}{|c}{ (from Kupfer 1998) } \\
\hline Radionuclide & $\begin{array}{c}\text { Amount (Curies) } \\
\text { (Decayed to 1/1/1994) }\end{array}$ \\
\hline H - 3 & 34,000 \\
\hline Se- 79 & 773 \\
\hline Sr -90 & $71,600,000$ \\
\hline Tc - 99 & 32,600 \\
\hline Sn- 126 & 1,190 \\
\hline I -129 & 63 \\
\hline Cs -137 & $46,400,000$ \\
\hline U -235 & 15 \\
\hline U - 238 & 322 \\
\hline Pu - 239 & 39,000 \\
\hline
\end{tabular}

Over the next 30 years, it is planned to retrieve the waste from the tanks and separate it into two waste streams, which will then be immobilized (TPA 1996). The high-level waste stream will contain most of the radionuclides. The immobilized high-level waste will be stored at the Hanford Site until it is transferred to a federally licensed geologic repository. The lowactivity waste will contain most of the non-radioactive chemical constituents of the tank waste. The immobilized low-activity waste (about 200,000 cubic meters) will be disposed of on site in steel containers. 
The Department of Energy (DOE) has entered into a contract with BNFL, Inc. (BNFL/DOE 1998) for tank waste treatment and immobilization services. Vitrification is the required method of immobilization for both the high-level and low-activity waste streams. However, the initial glass formulations have not yet been determined. The ILAW steel containers (about a meter in length in each dimension) are to last a minimum of 50 years. The long-term contaminant release rate is expected to be a few parts per million per year.

The current plans are to dispose of the ILAW containers in large underground concrete vaults (on the order of 20 to 40 meters long by 10 meters wide by 10 meters high). A surface barrier will be placed over the vault with the top of the waste being about 5 meters below the resulting ground surface. Four vaults, constructed as part of the Double-She11 Tank Waste Grout Disposal Program and are located at the eastern edge of the 200 East Area, could store about $4 \%$ of the ILAW. The remaining waste is planned to be disposed in new facilities in the south central part of the 200 East Area (Rutherford 1997) (See Figure 2.1). However, on-going engineering studies may indicate the benefits of other disposal options.

Figure 2.1 Location of the Disposal Vaults

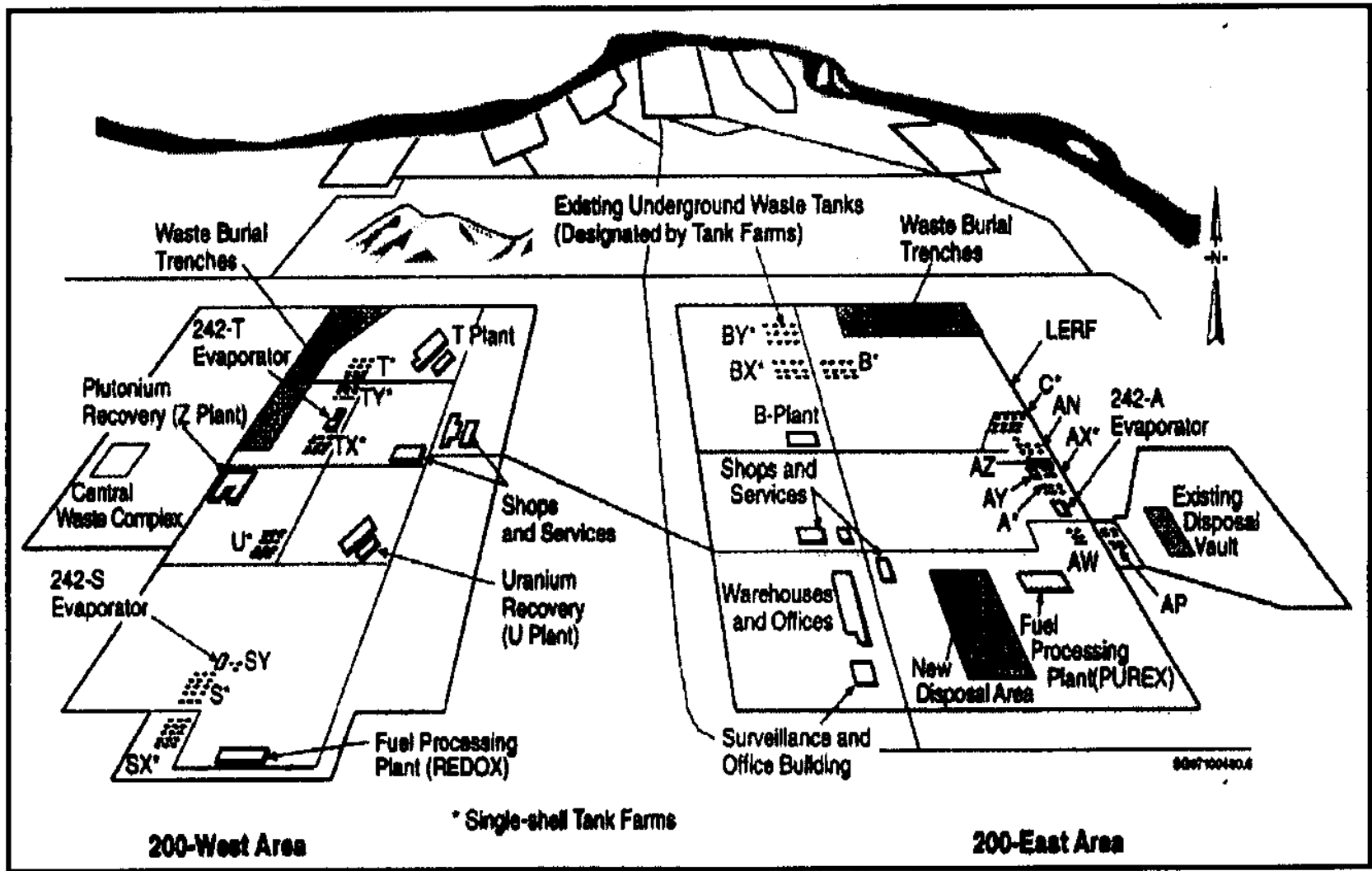

(The four existing disposal vaults are located at the just east of the AP Tank. The new disposal facility is located in the south-central part of the 200 East Area. The tank farms are identified by their letter names, e.g. AP) 


\section{$2.2 \quad$ Hanford Site}

The Hanford Site is located in south central Washington State (See Figure 2.). Because this site lies in the rain shadow of the Cascade Mountains, there is little precipitation most of which is removed from the soil by evaporation and plant transpiration. Thus, the Hanford Site is characterized by having a very small average moisture infiltration rate to the water table.

\section{Figure 2.2 Location of the Hanford Site}

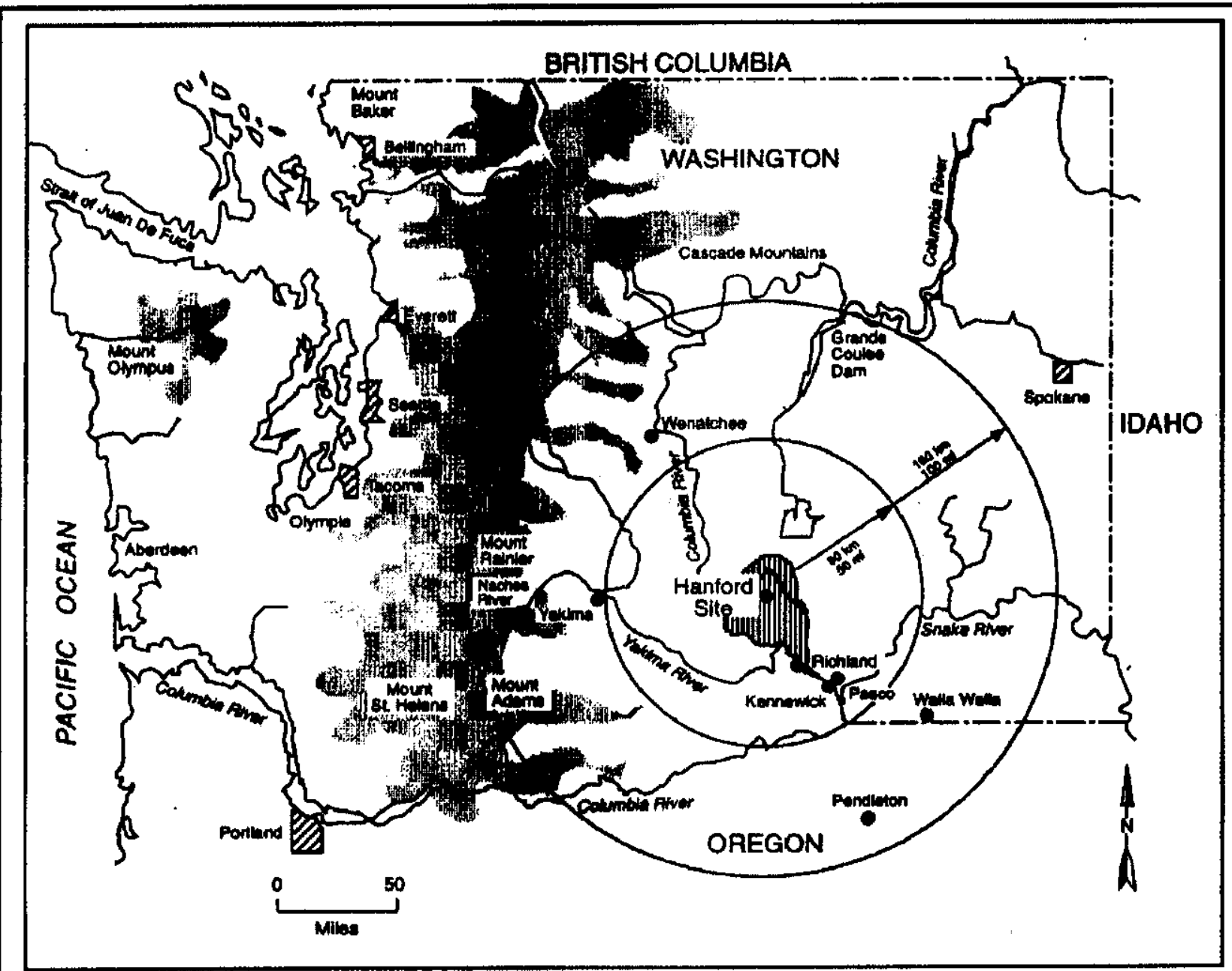


The Hanford Site lies in the Pasco Basin of the Columbia Intermontane Province. This province is the product of the Miocene continental flood, basalt volcanism, and regional deformation that occurred 6 to 17.5 million years ago. Glacier-related flooding has had a major impact on the physical geography. Cataclysmic flooding occurred when ice dams in western Montana and northern Idaho were breached, allowing large volumes of water to spill across eastern and central Washington. The last series of major floods occurred about 13,000 years ago, during the late Pleistocene Epoch. Interconnected flood channels, giant current ripples, and giant flood bars are among the landforms created by the floods. These formations resulted in heterogeneous and discontinuous characteristics for sediments ranging in size from silts to coarse gravels.

The top three geologic strata at the disposal site locations (the Holocene deposits, the Hanford formation, and, the Ringold Formation) have important roles in the performance assessment. More details are given in Mann 1998.

During the Holocene Epoch (the last 11,000 years), winds have locally reworked the flood sediments. The winds deposited dune sands in the lower elevation and loess (very fine wind-blown silts) around the margins of the Pasco Basin. Generally, anchoring vegetation has stabilized sand dunes. There is little potential for landslides, flooding, volanicism, or earthquakes at the disposal sites.

The Hanford formation was deposited by the catastrophic ice age flooding. The formation consists of pebble-to-boulder sized gravel, fine- to coarse-grained sand, and silt. It can be divided into two main facies: coarse-grained or gravelly deposits and fine-grained or sandy and silty deposits. The gravelly facies consists of coarse-grained sand and granule-to-boulder sized gravel. These gravels often lack matrix material and have an open framework appearance. The gravelly facies was deposited by high-energy floodwaters in flood bars and along channelways. The sand and silt facies consist of silt and fine- to coarse-grained sand that commonly display normally graded rhythmites a few centimeters to several tens of centimeters thick in outcrop (Myers 1979, DOE 1988b). These sediments were deposited under slackwater conditions and in backflooded areas (DOE 1988b). Clastic dikes are vertical features occasionally seen in the Hanford formation. In clastic dikes coarser Hanford formation materials surround a vertical hexagonal structure of very-fine grained sand. At the location of the disposal facilities, the Hanford formation is about 90 to $105 \mathrm{~m} \mathrm{(300} \mathrm{to} 345 \mathrm{ft})$ thick and consists predominantly of sands and gravelly sands. The sandy sequence is interpreted to lie between a slightly gravelly sand and a lower sandy gravel to gravelly sand. The Hanford formation thickens both to the north and south of the site of the new disposal facilities.

The Ringold Formation is assigned to a late Miocene to Pliocene age (Fecht 1987, DOE 1988b) and consists of clay, silt, compacted mud, fine- to coarse-grained sand, and granular to cobble gravel. In general, it tends to be finer-grained, or siltier, in the upper parts just below the Hanford formation. At the existing vaults site, the Ringold Formation starts about 90 meters (300 feet) below the unperturbed surface. At this location, the Ringold Formation is about 25 to 32 meters ( 82 to 105 feet) thick. At the site of the new disposal facilities, the Formation begins at about 100 meters ( 330 feet) and is about 30 to 38 meters (100 to 125 feet) thick. In both cases the Ringold Formation lies atop the Columbia River Basalt Group. 


\subsection{Future Land Use}

In 1992, DOE, EPA, and Ecology gathered a group of stakeholders to study future land use of the Hanford Site. This Hanford Future Site Uses Working Group issued a summary (HFSUWG 1992a) and a detailed report (HFSUWG 1992b) of its findings. The draft Hanford Remediation Action Environmental Impact Statement and Comprehensive Land Use Plan (DOE 1996) is heavily based on the work of the Hanford Future Site Uses Working Group. However, DOE's land use planning extends for only 50 years instead of the 100 years forecast by the working group.

HFSUWG (1992a) contains the following statement about near-term use of the 200 Areas, called the Central Plateau in the report.

"The presence of many different types of radionuclides and hazardous constituents in various forms and combinations throughout the site poses a key challenge to the Hanford cleanup. To facilitate cleanup of the rest of the site, wastes from throughout the Hanford site should be concentrated in the Central Plateau...Waste storage, treatment, and disposal activities in the Central Plateau should be concentrated within this area as well, whenever feasible, to minimize the amount of land devoted to, or contaminated by, waste management activities. This principle of minimizing land used for waste management should specifically be considered in imminent near-term decisions about utilizing additional uncontaminated Central Plateau lands for permanent disposal of grout."

The report continues on the subject of future use options (HFSUWG 1992a),

"In general, the Working Group desires that the overall cleanup criteria for the Central Plateau should enable general usage of the land and groundwater for other than waste management activities in the horizon of 100 years from the decommissioning of waste management facilities and closure of waste disposal areas."

Based on conversations of the working group, no definition of "general use" could be agreed on. For the "foreseeable future" the working group developed options involving waste treatment, storage, and disposal of DOE low-level radioactive waste. The differences among the options are whether offsite waste (radioactive and/or hazardous) would be allowed to be disposed of on the Hanford Site. 
Finally (HFSUWG 1992a),

"The working group identified a single cleanup scenario for the Central Plateau.

This scenario assumes that future uses of the surface, subsurface and groundwater in and immediately surrounding the 200 West and 200 East Areas would be exclusive... Surrounding the exclusive area would be a temporary surface and subsurface exclusive buffer zone composed of at least the rest of the Central Plateau...As the risks from the waste management activities decrease, it is expected that the buffer zone would shrink commensurately."

For nearer term land use planning, as part of the Washington State Growth Management Act of 1991, Benton County is identifying land uses for the Hanford Site. This plan treats the 200 Areas as industrial areas surrounded by "critical areas." By state law, "critical areas" are defined as land to be protected from use because of wildlife habitat or geologic or environmental conditions. Only the following areas were found suitable for development:

The McGee Ranch area to the northwest of the 200 West Area (at least $6 \mathrm{~km}$ [4 mi] away), where farming would be allowed

The area to the east of the 200 East Area (a minimum of $5 \mathrm{~km}$ [ $3 \mathrm{mi}$ ] away), where research and development activities would be allowed.

However, any formal land use planning is not expected to be accurate over the hundreds to hundreds of thousands of years covered in this analysis.

The future site boundary is shown in Figure 2.3. 
Figure 2.3 Location of the Future Site Boundary

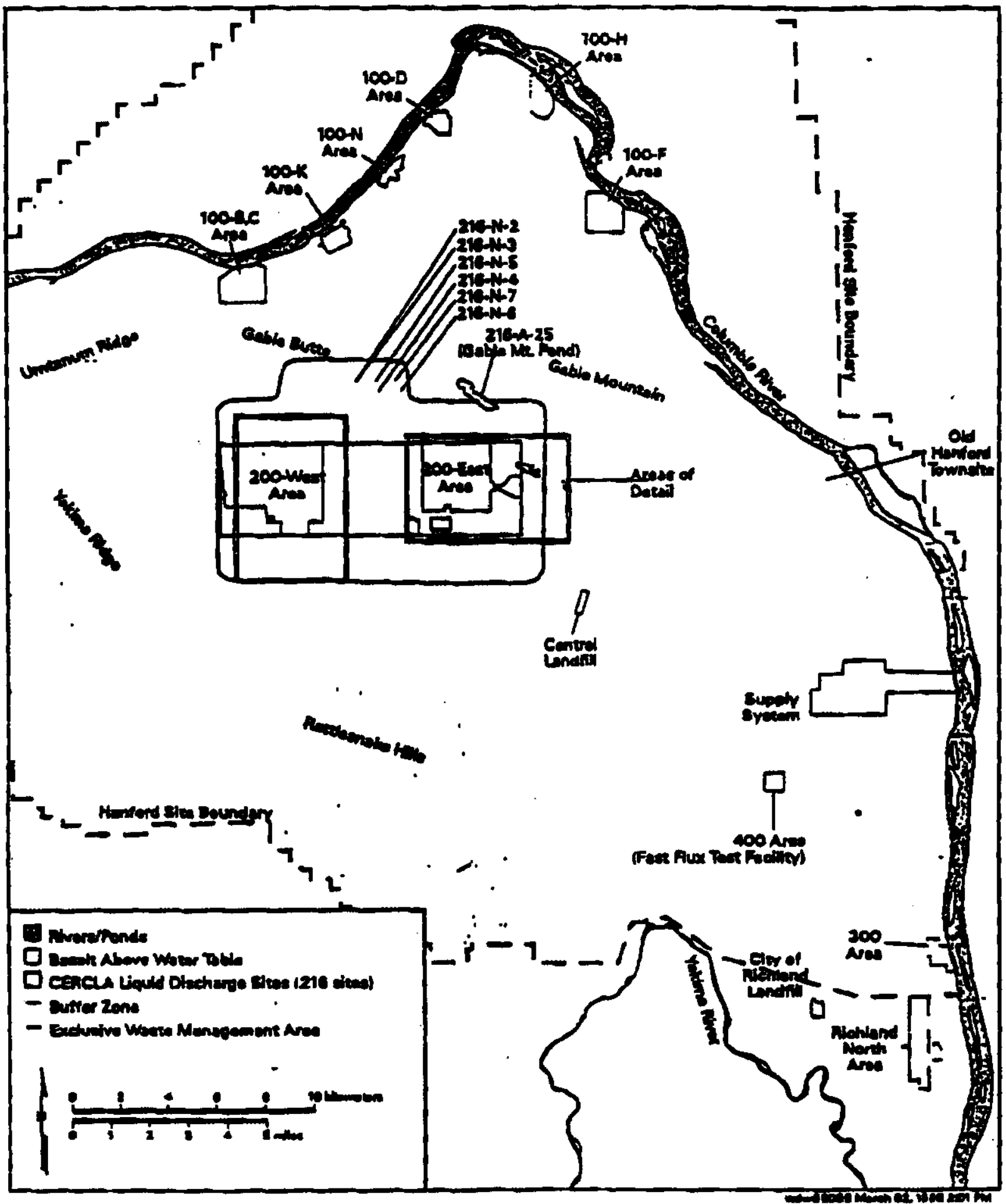


HNF-EP-0828, Rev.3

This page intentionally left blank 


\subsection{ALL-PATHWAYS AND GROUNDWATER}

Previous Hanford Site performance assessments (Kincaid 1995, Mann 1998, Wood 1995, Wood 1996) have shown that the main pathway that results in exposure will involve the following eight steps

1) Precipitation (rain or snow) falls on the ground with much of the water lost to the atmosphere due to evaporation or transpiration through plant leaves. The remaining water infiltrates the soil below the surface at a very low rate.

2) The water moves downward, but some of the water is diverted by any intact sandgravel capillary barrier.

3) The water that is not diverted away from the waste may be chemically modified by the local environment, interacts with the waste form, and accumulates contaminants.

4) The water (possibly a reduced amount because waste form dissolution and mineral formation consumes water) leaves the disposal facility carrying contaminants with it. Some contaminants may interact with the material in the disposal facility, slowing the release of contaminants to the surrounding natural environment.

5) Contaminated water moves through the undisturbed, unsaturated zone (vadose zone) below the disposal facility down to the unconfined aquifer. The contaminants may interact with soil sediments causing further retardation. Changes to the properties of the natural system are considered, but are not major.

6) The water and contaminants move and mix with the water in the unconfined aquifer until they are extracted from the aquifer and brought to the surface or until they reach the Columbia River.

7) Contaminants are extracted by being carried to the surface with groundwater being pumped through a well.

8) The contaminants result in human exposure through a variety of exposure pathways (ingestion, inhalation, dermal contact, and external radiation).

Figure 3.1 shows these eight steps (which remain unchanged from the previous ILAW PA) as a flow chart. 


\section{Figure 3.1 Sequential Steps for Groundwater Pathway}

1) Water starts downward journey from the near surface region

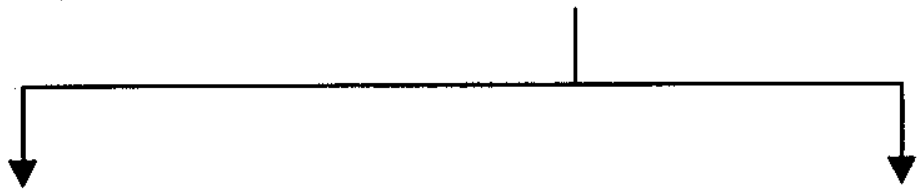

2) some of the water is diverted by a capillary barrier

3) Water (possibly chemically modified) interacts with waste form, and accumulates contaminants

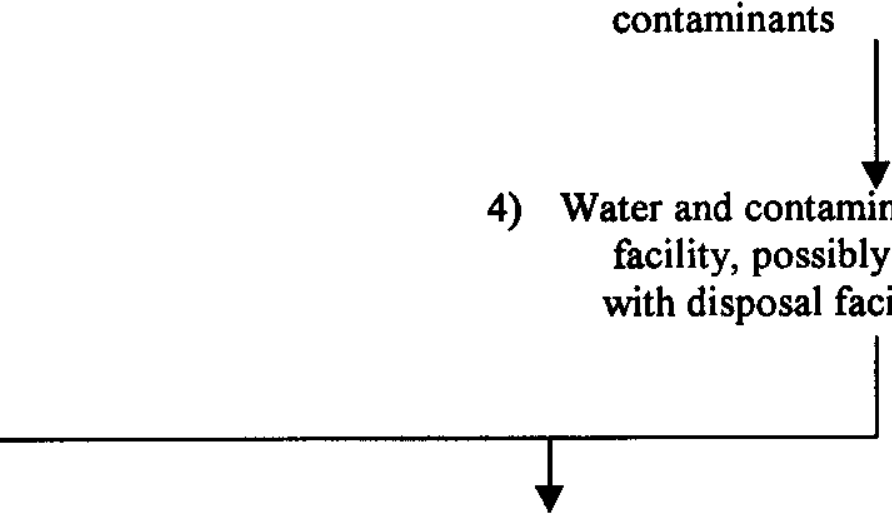

5) Water and contaminants move downward through the vadose zone.<smiles>C[13CH2]</smiles>

6) The contaminants move dowgradient in the unconfined aquifer, mixing with the groundwater, diluting the contaminant concentration.

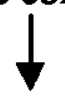

7) Water and contaminants are pumped from a well to the surface<smiles>C1C[Te]1</smiles>

8) Humans receive exposure from contaminants. 
HNF-EP-0828, Rev.3

\subsection{Base Case}

\subsubsection{General Description}

The general description of the base case scenario is the one described immediately above and displayed in Figure 3.1. Explicit numerical simulations will be performed from the present to 100,000 years in the future using best-estimate values for all parameters. Such extended calculations are required because of the overlapping in time of the various contaminant plumes. The 1998 ILAW PA (Mann 1998) showed that the second most mobile radionuclides (such as uranium and its daughters) peaked at about 50,000 years, a time at which the most mobile . radionuclides (technetium, selenium, and many chemicals) were still significant. Comparisons to the performance objectives will be made at 1,000 years and at 10,000 years after closure of the ILAW disposal facility (which is assumed to be in 2030).

Details for important categories of information are in the following subsections. Sections 3.2 through 3.5 contain the uncertainty, sensitivity, and reasonably bounding cases.

\subsubsection{End State}

The Department of Energy intends to retain the 200 Areas as long as necessary to protect human health (DOE 1996). Nonetheless, the new DOE Order on radioactive waste management (DOE 1999a) requires that the compliance point be the point of maximum exposure not nearer than 100 meters downgradient. Calculations of contaminant transport will determine the point of maximum exposure. Calculations will also be performed at the future site boundary as well as near the Columbia River. The calculations will consider the spatial overlap of the two disposal locations, but will not consider the overlap with other Hanford Site activities. The Composite Analysis for the Low-Level Waste Disposal in the 200 Area Plateau of the Hanford Site (Kincaid 1998 and revisions) calculates the effect of any overlap with other Hanford Site actions.

Scattered residential farms are assumed. Much of the area surrounding the Hanford Site contains irrigated farming sites. However, because of the low groundwater flow, because of the large vertical and horizontal distances from the Columbia River, and because of the difficulty to obtain water rights (Prosser 1999), it is unlikely that irrigated farming will occur and thus a dry land farming scenario is assumed. Parameters describing well construction and use will be taken from Future Hanford Site Farming Scenarios (Prosser 1999).

\subsubsection{Engineered Facility}

Immobilized low-activity waste is planned to be disposed at the two locations stated in Chapter 2. At each location, the waste will be disposed in subsurface concrete vaults that are topped by surface barriers designed to reduce water infiltration. The important parameters in modeling moisture flow, contaminant release, and contaminant transport at the disposal facility location are the elements of the disposal facility design governing moisture flow, the amount of water entering the facility (the infiltration rate), how the water moves in the facility (hydraulic 
processes and properties), and how contaminants interact with the disposal structure (geochemical processes and parameters).

Only conceptual models for the disposal facilities (FDNW 1998a, FDNW 1998b) are available. The parameters to be used to describe the disposal facility in the modeling shall be taken from Disposal Facility Parameters to be Used in the 2001 Hanford Low-Activity Tank Waste Performance Assessment (Puigh 1999) which is based on these conceptual models.

The infiltration rate through the surface barrier will be taken from the Recharge Data Package for the Immobilized Low-Activity Tank Waste 200I Performance Assessment (Fayer 1999). These estimates will be based on long-term lysimeter measurements, measurements of $\mathrm{Cl}$ and ${ }^{36} \mathrm{Cl}$ tracers, and detailed modeling of surface barriers. Values will be a function of space (under the surface barrier, near the barrier, and far from the barrier) and of time (intact and degraded surface barriers).

Hydraulic properties for the materials in the engineered facilities will be taken from the Near-Field Hydrology Data Package for thee Immobilized Low-Activity Waste 2001 Performance Assessment (Meyer 1999). The properties will be based on both existing literature and laboratory measurements including some laboratory measurements as a function of $\mathrm{pH}$. Both advection and diffusion are considered. Degradation of the components of the engineered system will be accounted for by varying the hydraulic parameters as a function of time.

Chemical parameters will be taken from Geochemical Data Package for the Hanford Low-Activity Tank Waste Performance Assessment (Kaplan 1999). The properties will be based on, in part, laboratory measurements of geochemical reactions as a function of $\mathrm{pH}$ and ionic strength. Time-dependent effects will be explicitly considered in many of the performance assessment calculations.

\subsubsection{Inventory}

Impacts to the receptor are directly proportional to the inventory of key contaminants (e.g. ${ }^{99} \mathrm{Tc}$ ). There will be a different inventory in the various $\mathrm{LAW}$ packages as there is a significant variation in the waste in the various Hanford single- and double-shell tanks. ILAW package inventories will be taken from the Immobilized Low-Activity Tank Waste Inventory Data Package (Wootan 1999) which will be based on the best basis global and tank-by-tank inventories of the TWRS Characterization Program (Kupfer 1998) and on chemical separation efficiencies of the BNFL, INC. treatment process. The estimate will also reflect maximum concentrations required by NRC Class limits (10 CFR 61), by RCRA restrictions (10 CFR 261, 10 CFR 264, 10 CFR 269, and WAC 173-303), and by the contract between BNFL, Inc. and DOE (BNFL/DOE 1998). It is assumed that these requirements will not change with time. Inventories of hazardous materials that are part of the engineered disposal facility will be identified in Disposal Facility Parameters to be Used in the 2001 Hanford Low-Activity Tank Waste Performance Assessment (Puigh 1999). 


\subsubsection{Immobilized Low-Activity Waste}

Based on the results of the previous ILAW PA (Mann 1998), the release rate from the waste form is a critical parameter. Such release rates depend on the waste form, the surrounding moisture content, the presence of key compounds (e.g. silic acid and secondary phases), as well as other environmental conditions (e.g. pH). Thus the release rate will depend on both the location of the waste form in the facility and will vary with time.

The waste form calculations will not only represent the initial release of contaminants from the glass, but also how the contaminants interact with secondary phases and with components of the engineered system. The calculations will also determine the amount of water consumed during these reactions.

Waste Form Release Data Package for the 2001 Immobilized Low-Activity Tank Waste Performance Assessment (McGrail 1999) will provide the data for calculating glass matrix dissolution, for the release of sodium from the glass matrix through ion exchange reactions, and for the creation and destruction of secondary phases. Such data are based on extensive experiments performed by both Argonne and Pacific Northwest National Laboratories following the research strategy contained in A Strategy to Conduct an Analysis of the Long-Term Performance of Low-Activity Waste Glass in a Shallow Subsurface Disposal System at Hanford (McGrail 1998). These experiments include the Product Consistency Test (PCT), Pressurized Unsaturated Flow (PUF) test, Single Pass Flow Through (SPFT) test, and Vapor Hydration Test (VHT).

The incoming moisture flow will come from simulations of the engineered system. Hydraulic parameters for filler material and the degraded waste form will come from the NearField Hydrology Data Package for thee Immobilized Low-Activity Waste 2001 Performance Assessment (Meyer 1999). The chemical interactions between the contaminants and the engineered materials are documented in Kaplan 1999. Impurities in the water entering the waste zone will be explicitly calculated.

\subsubsection{Geotechnical Data}

Transport in the vadose zone provides a significant delay in the time required before released contaminants will reach the biosphere. Transport in the groundwater further dilutes the contaminants. Although the underlying parameters in these models do not change with time as these parameters describe the properties of a stable system, vadose zone and groundwater calculations are time-dependent because the boundary conditions (recharge, groundwater inflow, and contaminant inflow) do change with time.

Inputs of moisture flow and contaminant release come from the engineered system moisture flow and from the waste form calculations. Hydraulic parameters for the vadose zone will come from the Far-Field Hydrology Data Package for Immobilized Low-Activity Tank Waste Performance Assessment (Khaleel 1999). The chemical interactions between the contaminants and the vadose zone soil sediments are documented in Kaplan 1999. Both the 
HNF-EP-0828, Rev.3

geohydrologic and the geochemical parameters are derived from site-specific subsurface samples as well as other Hanford Site samples, corrected for upscaling from laboratory-size measurements to field-scale use. The hydraulic and geochemical data are expected to depend on the startigraphic strata. The strata will be defined in the Geologic Data Package for 2001 Immobilized Low-Activity Tank Waste Performance Assessment (Reidel 1999).

The contaminant flux from the vadose zone will be fed into the groundwater calculations. The Hanford Site is developing a site wide aquifer model for calculating groundwater flow and contaminant transport for impact assessments. The aquifer model and its associated database will be used for the groundwater calculations.

\subsubsection{Receptor}

As noted in section 3.1.2, a dry land residential farming scenario is assumed. Parameters for such a farming scenario will be taken from Future Hanford Site Farming Scenarios (Prosser 1999). Dosimetry parameters will follow standard Hanford Site practices (DOE 1995) and will be taken from Data and Assumptions for Estimates of Radiation Doses for the Immobilized LowActivity Hanford Tank Waste Performance Assessment (Rittmann 1999).

\section{$3.2 \quad$ ALARA Cases}

The DOE Orders on Radioactive Waste Management (DOE 1988a and DOE 1999a) require that sensitivity calculations be performed to show that the design for the disposal action achieves impacts that are as low as reasonably gchievable (ALARA). This version of the ILAW PA will analyze three areas:

$-\quad$ Facility design
- $\quad$ Inventory
Waste Form.

The ALARA cases will also determine the effect on impacts from the uncertainty of key parameters in these three areas.

\subsubsection{Facility Design}

As noted in subsection 3.1.3, only conceptual designs (FDNW 1998a, FDNW 1998b) are available for the disposal facilities. Therefore, a major goal of the performance assessment is that the results of the PA will be used to optimize the disposal facility design. Sensitivity cases will be taken from Disposal Facility Parameters to be Used in the 2001 Hanford Low-Activity Tank Waste Performance Assessment (Puigh 1999), the Recharge Data Package for the Immobilized Low-Activity Tank Waste 2001 Performance Assessment (Fayer 1999), the NearField Hydrology Data Package for the Immobilized Low-Activity Waste 2001 Performance Assessment (Meyer 1999), and the Geochemical Data Package for the Hanford Low-Activity Tank Waste Performance Assessment (Kaplan 1999). Among the items to be investigated are 
- different surface barriers

- $\quad$ presence of hydraulic diverters (both horizontal and vertical)

- different filler materials between the ILAW packages and between the ILAW packages and the disposal structure

- different material degradation rates

- $\quad$ subsidence of the IIAW packages

- different facility layouts.

\subsubsection{Inventory}

The uncertainty of the inventory of ILAW packages in a disposal facility arises from

- uncertainty in the inventory of each tank (and in the global inventory)

- uncertainty in the order in which the waste will be retrieved from the tanks

- uncertainty in how BNFL, Inc. will treat the waste (i.e. separate tank waste into low-activity and high-level fractions and how much waste will go into the product).

Uncertainty cases will be based on the uncertainty data presented in the Immobilized LowActivity Tank Waste Inventory Data Package (Wootan 1999). The emphasis will be on contaminants (such as Tc) with the greatest impacts and on processes (such as off-site transfers and waste treatment) that have large impacts and are most susceptible to modification.

\subsubsection{Waste Form}

BNFL, Inc. has not yet determined the waste form that will be used during production. Uncertainty cases will be taken from Parameters for the Calculation of Waste Form Release for the 2001 Hanford Low-Activity Tank Waste Performance Assessment (McGrail 1999). The emphasis will be on different waste form formulations, waste loadings, and cooling rates as well as uncertainty in extrapolating laboratory measurements to long-term performance.

\subsection{Uncertainty Cases}

\subsubsection{Geotechnical Alternatives}

Our understanding of the vadose zone and the unconfined aquifer is incomplete. The uncertainty in vadose zone parameters will be taken the Geologic Properties for the 2001 Hanford Low-Activity Tank Waste Performance Assessment (Reidel 1999), the Estimated Hydrologic Properties for the 2001 Hanford Low-Activity Tank Waste Performance Assessment (Khaleel 1999), and the Geochemical Data Package for the Hanford Low-Activity Tank Waste Performance Assessment (Kaplan 1999). Key parameters to be investigated include hydraulic properties, diffusion parameters, dispersion parameters, chemical retardation parameters, and initial moisture conditions. Uncertainty cases in groundwater modeling will be defined in consultation with the Hanford Site Consolidated Groundwater Program. 


\subsubsection{Different Future End States}

The future is by its nature quite uncertain. Therefore general conditions will be varied. Irrigation will be considered in various parts of the Hanford Site. In particular, irrigation over the disposal site shall be investigated. Other differences that are likely to be investigated include different well parameters.

\subsubsection{Different Receptor Scenarios}

Predicting future human activities is quite uncertain. Uncertainty cases will be taken from the Future Hanford Site Farming Scenarios (Prosser 1999) and from the Data and Assumptions for Estimates of Radiation Doses for the Immobilized Low-Activity Hanford Tank Waste Performance Assessment (Rittmann 1999). In particular, Prosser 1999 will provide uncertainties in well parameters, while Rittmann 1999 will provide uncertainties in dosimetry conversion factors. Rittmann 1999 will also provide alternative receptor scenarios, including Native American and industrial work scenarios. 


\subsection{ATMOSPHERIC RELEASES}

The previous performance assessment (Mann 1998) showed that using conservative assumptions that releases to the atmosphere are many orders of magnitude (four in the case of radon releases and nine for other gases) less than performance objectives.

The release rate of gases from the waste form will be taken as the same as the dissolution rate of the glass (see subsection 3.1.5). The gases would then diffuse up through the disposal facility without taking credit for any intact-engineered barriers (such as metal containers or concrete structures). Diffusion parameters will be taken from the Near-Field Hydrology Data Package for the Immobilized Low-Activity Waste 2001 Performance Assessment (Meyer 1999). 
HNF-EP-0828, Rev.3

This page intentionally left blank 
HNF-EP-0828, Rev.3

\subsection{INADVERTENT INTRUDER}

Following the practice of the Nuclear Regulatory Commission (NRC 1998, NRC 1997), three scenarios were considered:

- A basement is excavated which extends into the waste and hence contaminants are brought to the surface

- A well is drilled through the waste, bringing contaminants to the surface,

- Contaminants that have been brought to the surface are mixed with the surrounding soil as a residential farmer works the soil.

Because the waste will be below ( $>5$ meters) the levels that basement excavations are dug in the Columbia Basin region, the first scenario (basement excavation) is not treated. The other two scenarios are treated.

\section{$5.1 \quad$ Drilling}

A likely occurrence is that a borehole will be drilled in order to obtained water either from the unconfined aquifer or, more likely, from the more voluminous confined aquifer. Because of the large gravels underlying the Hanford Site, robust drilling tools are likely to be used. Well parameters are taken from the Future Hanford Site Farming Scenarios (Prosser 1999). Exposure parameters are taken from the Data and Assumptions for Estimates of Radiation Doses for the Immobilized Low-Activity Hanford Tank Waste Performance Assessment (Rittmann 1999). No credit is taken that the driller would recognize that large blocks of glass would be brought to the surface (an unnatural occurrence). It is assumed that drilling fractures the waste form into rock-size chunks, consistent with that typically produced by ordinary drilling techniques.

\subsection{Residential Farmer}

After the driller leaves, with the contaminated soil still present, a residential farmer with his family occupies the land. The family is exposed to contaminants by direct irradiation from the soil, and by eating crops and animals raised on the contaminated soil. Use of contaminated groundwater is not considered as part of this scenario (because following DOE guidance for DOE $O 435.1$ the intruder and all-pathways scenarios are separated) as it is considered under the all pathways/groundwater scenarios. Again, credit is taken that the waste form brought to the surface will still be coarsely divided. 


\section{HNF-EP-0828, Rev.3}

\subsection{Uncertainty Cases}

Uncertainty cases will be based on uncertainties developed in the Future Hanford Site Farming Scenarios (Prosser 1999) and the Data and Assumptions for Estimates of Radiation Doses for the Immobilized Low-Activity Hanford Tank Waste Performance Assessment (Rittmann 1999). Cases that will be included will be the volume of waste taken from the disposal facility, the type of contaminants in that volume, how intact the retrieved waste form is, and the various exposure scenarios. 


\subsection{PUBLIC INVOLVEMENT}

It is important that Hanford stakeholders have the opportunity to affect the scenarios analyzed in the ILAW performance assessment. Public comments were requested on the original version of this document (Mann 1994) as well as revision 2 (Mann 1999b).

A summary of the initial version of the scenarios was sent to each member and alternate of the Hanford Advisory Board, to selected Hanford Site contractor employees, and to selected members of the DOE's Peer Review Panel and Performance Assessment Task Team. Their comments and corresponding responses to the previous version of this document are available for review (Murkowski 1995).

Revision 2 of this document was made available for public review following the public involvement procedures established by the Hanford Groundwater / Vadose Zone Integration Project (that is, announcements were made at biweekly meetings, the review period was noted on the published list of Integration Project activities, and the documents were available on the Integration Project's web site). Only the Oregon Office of Energy submitted comments (Blazek 1999) and these mainly dealt with waste classification, the extent of public announcement, and other general program activities. Because of the nature of the comments, no changes were made to revision 2 based on these comments. The comments from the Oregon Office of Energy as well as the responses (Taylor 1999) to them by the Department of Energy's Office of River Protection are available on request.

Comments on this version of the document should be sent to:

Frederick M. Mann

Fluor Daniel Northwest

Mail Stop H0-22

Post Office Box 1050

Richland, Washington 99352

Since calculations for the performance assessment will begin in October 1999, to be effective the comments should be sent as soon as possible. 
HNF-EP-0828, Rev.3

This page intentionally left blank 


\subsection{REFERENCES}

10 CFR 61, "Licensing Requirements for the Land disposal of Radioactive Waste," 10 CFR 61, U.S. Nuclear Regulatory Commission, Washington, D.C., May 25, 1989.

- $\quad$ Subpart C, "Performance Objectives," Sections 40 through 44.

- Subpart D, "Technical Requirements for Land Disposal Facilities," Sections 50 through 59.

40 CFR 61, "National Emission Standards for Hazardous Air Pollutants 40 CFR 61, Section 92, U.S. Environmental Protection Agency, Washington, D.C. December 15, 1989.

- Subpart H, "National Emission Standards for Emissions of Radionuclides Other than Radon from Department of Energy Facilities, Section 92.

- $\quad$ Subpart Q, "National Emission Standards for Radon Emissions from Department of Energy Facilities," Section 192.

40 CFR 141, "National Primary Drinking Water Regulations," 40 CFR 141, U.S. Environmental Protection Agency, Washington, D.C. December 24, 1975.

- $\quad$ Subpart B, "Maximum Contaminant Levels," Sections 11 through 16.

- Subpart G, "National Revised Primary Drinking Water Regulations: Maximum Contaminant Levels," Part 60 to 63.

40 CFR 261, "Identification and Listing of Hazardous Waste, "U. S. Environmental Protection Agency, Washington, D.C., August 31, 1993.

- Subpart B, "Criteria for Identifying the Characteristics of Hazardous Waste and for Listing Hazardous Waste," Sections 10 and 11.

- Subpart C, "Characteristics of Hazardous Waste," Sections 20 through 24.

40 CFR 264, "Standards for Owners and Operators of Hazardous Waste Treatment, Storage, and Disposal Facilities," U.S. Environmental Protection Agency, Washington, D.C., February $16,1993$.

- Subpart F, "Release from Solid Waste Management Units," Sections 90 to 101."

40 CFR 268, "Land Disposal Restrictions," U.S. Environmental Protection Agency, Washington, D.C., May 26, 1998.

- $\quad$ Subpart D, "Treatment Standards", Section 40 through 48.

Blazek 1999, M.L. Blazek (Oregon Office of Energy), letter to Fred Mann dated June 9, 1999, Salem, Oregon.

BNFL/DOE 1998, contract between BNFL, Inc. and the U.S. Department of Energy regarding TWRS Privatization, Contract number DE-AC06-96RL13308, Modification No. A005, July 25, 1998.

- $\quad$ Part 1, Section C, Item 2.2.2 contains the Immobilized Low-Activity Waste product requirements. 
Code of Federal Regulations. See reference under XX CFR YYY.

DOE Orders

DOE 0 435.1, "Radioactive Waste Management," see DOE 1999a.

DOE Order 5820.2A, "Radioactive Waste Management," see DOE 1988a.

DOE Order 5400.5, "Radiation Protection of the Public and the Environmental," see DOE 1993.

DOE 1988a, DOE Order 5820.2A, "Radioactive Waste Management," U.S. Department of Energy, Washington, D.C., September 26, 1988.

DOE 1988b, Consultation Draft Site Characterization Plan,_DOE/RW-0164, Volume 2, Page 3.4-16, U.S. Department of Energy, Washington, D.C., January 1988.

DOE 1993, "Radiation Protection of the Public and the Environment," DOE Order 5400.5, U.S. Department of Energy, Washington, D.C., January 7, 1993.

DOE 1995, Hanford Site Risk Assessment Methodology, DOE/RL-91-45, Rev. 3, U.S.

Department of Energy, Richland Operations Office, Richland, Washington, May 1995.

DOE 1996, Draft Hanford Remediation Action Environmental Impact Statement sand Comprehensive Land Use Plan, DOE/EIS-0222D, U.S. Department of Energy, Washington, D.C., August 1996.

DOE 1999a, DOE O 435.l, "Radioactive Waste Management," Draft DOE Order 435.1, U.S. Department of Energy, Washington, D.C., July 9, 1999.

DOE 1999b, Radioactive Waste Management Manual, DOE M 435.1, U.S. Department of Energy, Washington, D.C., July 9, 1999.

DOE 1999c, Implementation Guide for DOE M 435.1, DOE G 435.1, U.S. Department of Energy, Washington, D.C., July 9, 1999.

DOE 1999d, Format and Content Guide for U.S. Department of Energy Low-Level Disposal Facility Performance Assessments and Composite Analyses, DOE G 435.1-1, U.S. Department of Energy, Washington, D.C., September 30, 1999.

DOE 1999e, DOE O 435.1, Radioactive Waste Management, Technical Basis for DOE M 435.1, U.S. Department of Energy, Washington, D.C., September 30, 1999.

DOE /RL 1995Hanford Site Ground Water Protection Management Plan, DOE-RL-89-12, Rev. 2, U.S. Department of Energy, Washington, July 1995.

Fayer 1999, Recharge Data Package for the Immobilized Low-Activity Waste 2001 Performance Assessment, Pacific Northwest National Laboratory, Richland, Washington (to be published December 1999). 
HNF-EP- 0828, Rev. 3

FDNW 1998a, Immobilized Low-Activity Waste Interim Storage Facility, Project W-465 Conceptual Design Report, HNF-1975, Rev. 1, Fluor Daniel Northwest, Richland, Washington, March 1998.

FDNW 1998b, Conceptual Design Report for Immobilized Low-Activity Waste Disposal Facility Project, Project W-520, HNF-3013, Rev. B, Fluor Daniel Northwest, Richland, Washington, September 1998.

Fecht 1987, K.R. Fecht, S.P. Reidel, and A.M. Tallman, "Paleodrainage of the Columbia River System of the Columbia Plateau of Washington State - A Summary," Selected Papers on the Geology of Washington, Division of Geology and Earth Resources, Bulletin 77, p. 219-248, edited by J.E. Schuster.

HFSUWG 1992a, The Future for Hanford: Uses and Cleanup, Summary of the Final Report of the Hanford Future Site Uses Working Group, Document number 0026618, December 1992. The report is available through the Environmental Data Management Center, Lockheed Martin Information Services, Incorporated, Richland, Washington.

HFSUWG 1992b, The Future for Hanford: Uses and Cleamup, the Final Report of the Hanford Future Site Uses Working Group, Document number 0026619, December 1992. The report is available through the Environmental Data Management Center, Lockheed Martin Information Services, Incorporated, Richland, Washington.

Kaplan 1999, D.I. Kaplan and R.J. Serne, Geochemical Data Packages for the Hanford Immobilized Low-Activity Tank Waste Performance Assessment, Pacific Northwest National Laboratory, Richland, Washington (to be published December 1999).

Khaleel 1999, R. Khaleel, Far-Field Hydrology Data Packages for Immobilized Low-Activity Tank Waste Performance Assessment, HNF-4762, Rev.2, Fluor Daniel Northwest, Richland, Washington, December 1999.

Kincaid 1995, C. T. Kincaid, J.A. Voogd, J.W. Shade, J. H. Westsik, Jr, G. A. Whyatt, M.D. Freshley, M.G. Piepho, K.A. Blanchard, K. Rhoads, and B. G. Lauzon, Performance Assessment of Grouted Double Shell Tank Waste Disposal at Hanford, WHC-SD-WMEE-004, Rev. 1, Westinghouse Hanford Company, Richland, Washington, May 1995.

Kincaid 1998, C.T. Kincaid, M.P. Bergeron, C.R. Cole, M.D. Freshley, D.L. Strenge, P.D. Thorne, L.W. Vail, and S.K. Wurstner, Composite Analysis for the Low-Level Waste Disposal in the 200 Area Plateau of the Hanford Site, PNNL-11800, Pacific Northwest National Laboratory, Richland, Washington, March 1998.

Kupfer 1998, M.J. Kupfer, A.L. Boldt, B.A. Higley, K.M. Hodgson, L.W. Shelton, B.C. Simpson, R.A. Watrous, M.D. LeClair, G.L. Borsheim, R.T. Winward, R.M. Orme, N.G. Colton, S.L. Lambert, and W.W. Schulz, Standard Inventories of Chemicals and Radionuclides in Hanford Site Tank Wastes, HNF-SD-WM-TI-740, Rev. 2, Lockheed Martin Hanford Corporation, Richland, Washington, September 1998. 
HNF-EP-0828, Rev.3

Mann 1994, F.M. Mann, Scenarios of the Tank Waste Remediation Systems Low-Level Waste Disposal Program, WHC-EP-0828, Rev. 0, Westinghouse Hanford Company, October 1994.

Mann 1998, F.M. Mann, R.J. Puigh II, P.D. Rittmann, N.W. Kline, J.A. Voogd, Y. Chen, C.R. Eiholzer, C.T. Kincaid, B.P. McGrail, A.H. Lu, G.F. Williamson, N.R. Brown, and L.E. LaMont, Hanford Immobilized Low-Activity Tank Waste Performance Assessment, DOE/RL-97-69, U.S. Department of Energy, Richland Operations Office, Richland, Washington, March 1998.

Mann 1999a, F.M. Mann, Performance Objectives of The Hanford Immobilized Low-Activity Tank Waste Performance Assessment Activity, HNF-0826, Rev. 2, Lockheed Martin Hanford Corporation, Richland, Washington, March 1999.

Mann 1999b, F.M. Mann, Scenarios of the Tank Waste Remediation Systems Low-Level Waste Disposal Program, WHC-EP-0828, Rev. 2, Westinghouse Hanford Company, March 1999.

McGrail 1998, B.P. McGrail, W.L. Ebert, D.H. Bacon, and D.M. Strachan, A Strategy to Conduct an Analysis of the Long-Term Performance of Low-Activity Waste Glass in a Shallow Subsurface Disposal System at Hanford, PNNL-11834, Pacific Northwest National Laboratory, Richland, Washington, March 1998.

McGrail 1999, B.P. McGrail, D.H. Bacon, J.P. Icenhower, W.L. Ebert, P.F. Martin, H.T. Schaef, and E.A. Rodriguez, Parameters for the Calculation of Waste Form Release for the 2001 Hanford Low-Activity Tank Waste Performance Assessment, Pacific Northwest National Laboratory, Richland, Washington (to be published December 1999).

Meyer 1999, P.D. Meyer and R.J. Serne, Near-Field Hydrology Data Package for the Immobilized Low-Activity Waste 2001 Performance Assessment, Pacific Northwest National Laboratory (to be published December 1999).

Murkowski 1995, "Performance Objectives and Scenarios for the Glass Low-Level Waste Interim Performance Assessment," letter from R.J. Murkowski (Manager, Storage and Disposal Program, Westinghouse Hanford Company) to L. Erickson (U.S. Department of Energy, Richland Operations) dated January 27, 1995.

Myers 1979, C.W. Myers, S.M. Price, J.A. Caggiano, M.P. Cochran, W.J. Czimer, N.J. Davidson, R.C. Edwards, K.R. Fecht, G.E. Holmes, M.G. Jones, J.R. Kunk, R.D. Landon, R.K. Ledgerwood, J.T. Lillie, P.E. Long, T.H. Mitchell, E.H. Price, S.P. Reidel, and A.M. Tallman, Geologic Studies of the Columbia Plateau: A Status Report, RHOBWI-ST-4, Rockwell Hanford Operations, Richland, Washington, October 1979.

NRC 1988, Standard Review Plan for the Review of a License Application for a Low-Level Radioactive Waste Disposal Facility, NUREG-1200, Rev. 1, U.S. Nuclear Regulatory Commission, Washington, D.C. January 1988. 
NRC 1997, Branch Technical Position on Performance Assessment Methodology for Low-Level Disposal Facilities (draft for public comment). NUREG-1573. Low-Level Waste Management Branch, U.S. Nuclear Regulatory Commission, Washington, D.C., May 1997.

Prosser 1999, Future Hanford Site Farming Scenarios, U.S. Department of Agriculture Extension Station, Prosser, Washington (to be published December 1999).

Puigh 1999, R.J. Puigh II, Disposal Facility Parameters to be Used in the 2001 Hanford LowActivity Tank Waste Performance Assessment, HNF-4950, Rev. 0, Fluor Daniel Northwest, Richland, Washington, September 1999.

Reidel 1999, S.P. Reidel, Geologic Properties for the 2001 Hanford Low-Activity Tank Waste Performance Assessment, PNNL-12257, Rev. 2, Pacific Northwest National Laboratory, Richland, Washington, December 1999.

Rittmann 1999, P.D. Rittmann, Data and Assumptions for Estimates of Radiation Doses for the Immobilized Low-Activity Hanford Tank Waste Performance Assessment, HNF-???, Rev. 0, Fluor Daniel Northwest, Richland, Washington, December 1999).

Rutherford 1997, W.A. Rutherford (Director, Site Infrastructure Division), letter 97-SID-285 to H.J. Hatch (President, Fluor Daniel Hanford, Inc.), "Contract DE-AC06-96RL113200Approval of Tank Waste Remediation System Complex Site Evaluation Report," dated July 10, 1997, U.S. Department of Energy, Richland, Washington.

Taylor 1999, W.J. Taylor, letter to M.L. Blazek (Oregon Office of Energy) dated July 8, 1999, U.S. Department of Energy, Office of River Protection, Richland, Washington.

TPA 1996, Washington State Department of Ecology, United States Environmental Protection Agency, and the United States Department of Energy, Hanford Facility Agreement and Consent Order, Sixth Amendment, February 1996, The document is available from any of the parties.

WAC 173-201A, "Water quality Standards for Surface Waters of the State of Washington," WAC 173-201A, Washington State Department of Ecology, Olympia, Washington, December 18, 1997.

- "Toxic Substances," Section 040.

- "Radioactive Substances," Section 050.

WAC 173-303, "Dangerous Waste Regulations," Washington State Department of Ecology, Olympia, Washington, January 12, 1998.

- "Dangerous Waste Characteristics," Section 090.

- "Dangerous Waste Criteria," Section 100.

- $\quad$ "Releases from Regulated Units," Section 645.

Washington Administrative Code, see WAC XX-YYY. 
Wood 1995, M.I. Wood, R. Khaleel, P.D. Rittmann, A.H. Lu, S.H. Finfrock, R.J. Serne, and K.J. Cantrell, Performance Assessment for the Disposal of Low-Level Waste in the 200 West Area Burial Grounds, WHC-EP-0645, Westinghouse Hanford Company, Richland, Washington February 1995.

Wood 1996, M.I. Wood, R. Khaleel, P.D. Rittmann, A.H. Lu, S.H. Finfrock, T.H. DeLorenzo, and D.Y. Garbrick, Performance Assessment for the Disposal of Low-Level Waste in the 200 East Area Burial Grounds, WHC-EP-0875, Westinghouse Hanford Company, Richland, Washington, September 1996.

Wootan 1999, D.W. Wootan, Immobilized Low-Activity Tank Waste Inventory Data Package, HNF-4921, Fluor Daniel Northwest, Inc., Richland, Washington, August 1999. 


\section{DISTRIBUTION SHEET}

To

R. W. Root

Project Title/Work Order

HNF-EP-0828, Rev. 3, Scenarios for the Hanford Immobilized

Low-Activity Waste (ILAW) Performance Assessment

\begin{tabular}{|c|c|c|c|c|c|}
\hline Name & MSIN & $\begin{array}{c}\text { Text } \\
\text { With All } \\
\text { Attach. }\end{array}$ & Text Only & $\begin{array}{l}\text { Attach II } \\
\text { Appendix } \\
\text { Only }\end{array}$ & $\begin{array}{c}\text { EDT/ECN } \\
\text { Only }\end{array}$ \\
\hline \multicolumn{6}{|l|}{ DOE-RL } \\
\hline C. A. Babel & A2 -22 & $x$ & & & \\
\hline N. R. Brown & $\mathrm{A} 0-21$ & $x$ & & & \\
\hline R. D. Hilderbrand & H0-12 & $x$ & & ? & \\
\hline P. E. LaMont & $\mathrm{A} 0-21$ & $x$ & & & \\
\hline R. M. Yasek & s7-54 & $\mathrm{x}$ & & & \\
\hline \multicolumn{6}{|l|}{ BECHTEL HANFORD, INC. } \\
\hline D. H. Butler & но- 21 & $\mathrm{x}$ & & & \\
\hline B. H. Ford & $\mathrm{HO}-21$ & $\mathrm{x}$ & & & \\
\hline M. J. Graham & но-09 & $x$ & & & \\
\hline \multicolumn{6}{|l|}{ FLUOR DANIEL HANFORD } \\
\hline L. E. Borneman & G1-24 & $x$ & & & \\
\hline A. M. Umek & $57-40$ & $\mathrm{x}$ & & & \\
\hline J. D. Williams & H0-22 & $x$ & & & \\
\hline \multicolumn{6}{|l|}{ FLUOR DANIEL NORTHWEST } \\
\hline R. Khaleel & $B 4-43$ & $x$ & & 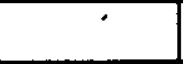 & \\
\hline F. M. Mann $(10)$ & но- 22 & $x$ & & & \\
\hline R. J. Puigh & B4-43 & $\mathrm{x}$ & & & \\
\hline P. D. Rittmann & B4-43 & $\mathrm{x}$ & & & \\
\hline \multicolumn{6}{|l|}{ Hanford Groundwater/Vadose Zone Integration } \\
\hline G. A. Jewel (For public distribution) (5) & HO-21 & $\mathrm{x}$ & & & \\
\hline \multicolumn{6}{|l|}{ LOCKHEED MARTIN HANFORD COMPANY } \\
\hline H. L. Boston & R2-53 & $x$ & & & \\
\hline K. C. Burgard & $54-45$ & $\mathrm{x}$ & & & \\
\hline C. C. Haass & $\mathrm{R} 1-04$ & $\mathrm{x}$ & & & \\
\hline A. J. Knepp & $\mathrm{HO}-22$ & $\mathrm{x}$ & & & \\
\hline D. A. Myers & но -22 & $x$ & & & \\
\hline R. W. Root & $\mathrm{R} 2-53$ & $x$ & & & \\
\hline
\end{tabular}

From

Frederick M. Mann

Page 1 of 2

Date August 11, 1999

EDT No. N/A

ECN No. N/A 


\section{DISTRIBUTION SHEET}

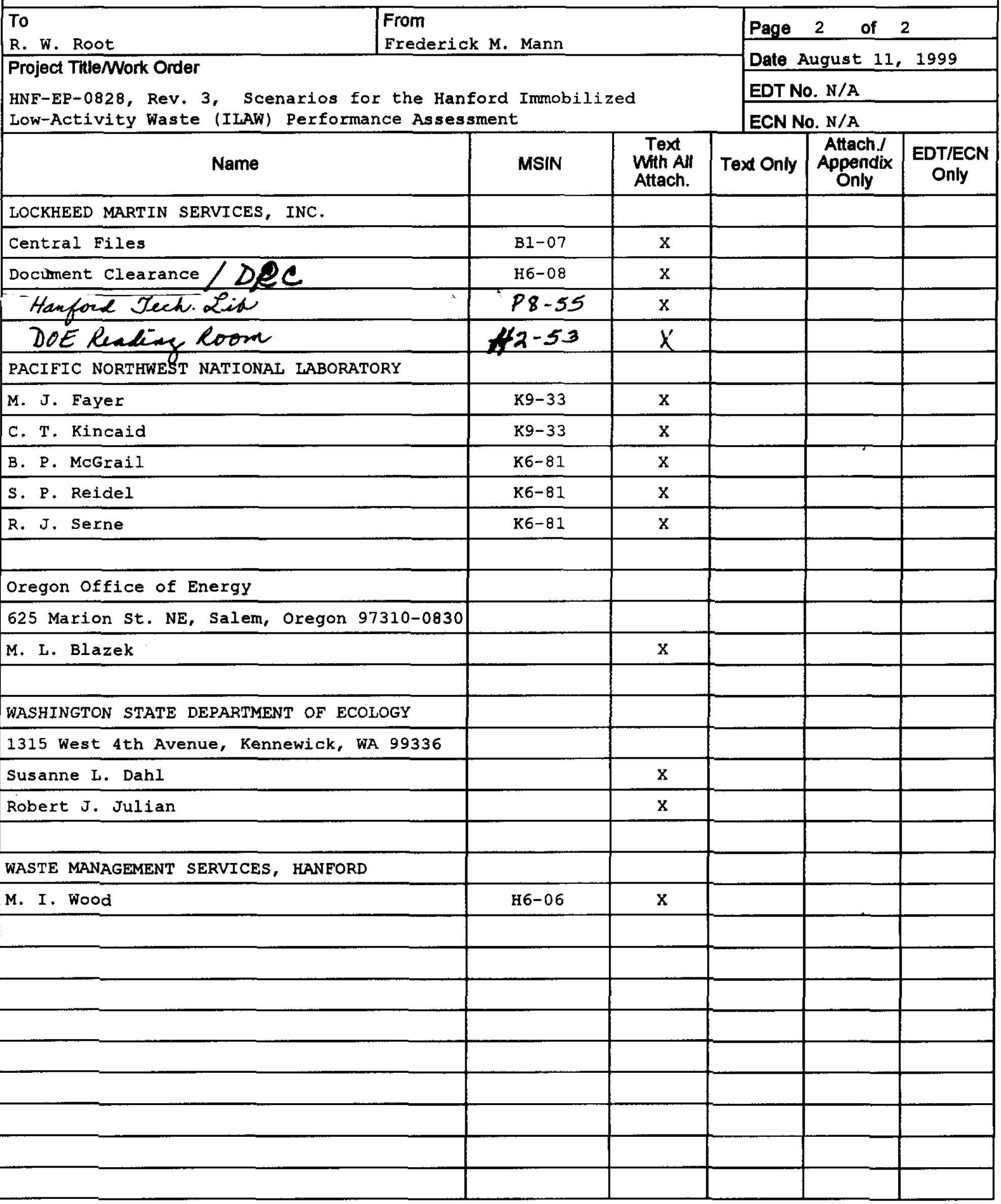

